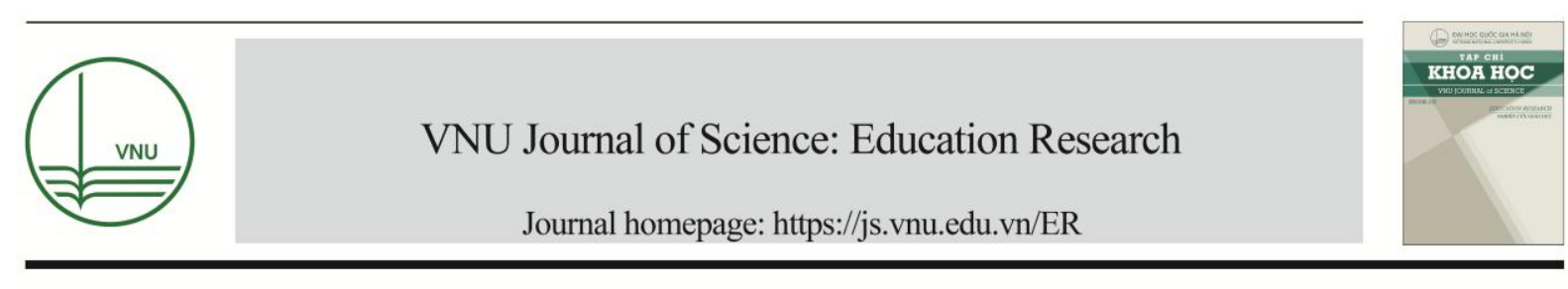

\title{
Multicultural Narrative of History Textbook
}

\author{
Akhmad Dwi Afiyadi", Leo Agung Sutimin, Sunardi \\ History Education Department, Sebelas Maret University, Surakarta, Indonesia
}

Received 09 June 2018

Revised 12 June 2018; Accepted 18 June 2018

\begin{abstract}
History textbook is a student's handbook used in a process of learning history with 2013 Curriculum. That textbook used a popular regressive approach. Through the textbook, students were invited to observe historical events in everyday life and also events occurred. The researchers analyzed the textbook using the Discourse-Historical Approach by Ruth Wodak. The approach included three layers of analysis, namely textual analysis, contextual analysis, and prospective criticism analysis. The multicultural narrative can be found throughout the book, especially in the categorization of historical relics space and historical events space. Textual and contextual meanings can be the basis or paradigm of education policy and praxis as a multicultural competence that is owned by the students themselves, both in solving problems in the classroom as well as in human life. Textbook is important for educational purposes in this area of multicultural competence. The continuation of this book for further analysis in the field of education is quite open, for example in the learning model with other relevant materials and so on. The researchers suggest developing the book in terms of both materials and the exploring of the potential possessed by students to transmit the multicultural values of books to students.
\end{abstract}

Keywords: History textbook, multicultural narrative, Discourse-Historical Approach, multicultural competence, multicultural values.

\section{Introduction}

The history discipline is taught at the school from the elementary to the secondary level. The materials are given during the lesson such as historical events that occurred in Indonesia. The historical construction on history textbooks becomes the source or medium in the process of learning history. Hence, the history textbook is part of the historical historiography work.

\footnotetext{
* Corresponding author.

Email: akhmaddwiafiyadi@gmail.com

https://doi.org/10.25073/2588-1159/vnuer.4150
}

History needs to be taught at schools because it can help people have a humanist attitude. The essence of the humanist attitude is to respect others and themselves [1]. This perspective fits the essence of a multicultural attitude which shows that everyone is part of us in distinction. Then as human, we can co-exist and admit the cultural, ethnic, and group differences in a diverse society.

History can be regarded as a discourse system, discourse which wants to say "something about something" [2]. The historical discourse is tied to the context of time which becomes the characteristic of historical events. 
The historical textbooks material itself is based on the curriculum. Theoretically, a curriculum is a political policy, therefore, the subject matter of historical textbooks cannot be separated from the political interests of the government. State political conditions also affect the curriculum and textbook material. This is because the history textbooks are the main media for developing national awareness and international awareness [3].

The historiography textbooks reflect the author's interpretation of historical material in the curriculum. The textbook's author interprets through two aspects, first is to interpret the subject matter in the curriculum into a textbook material and the second, the authors have to transform the historical facts into historical narratives. In writing the historical narrative, interpretation is influenced by the subjectivity of the author as in the writing of history. On the other hand, the historian is influenced by his attitude, assumptions, norms and values [4].

The writing reconstruction by compiling and assembling historical facts into the narrative will be made by the author in the form of interpretation. The construction of historical narrative shows a linguistic element. The postmodernist view found that language skills were an important part of seeing the historical truth. Language structure shows the relationship between words, sentences and intercostal relationships. The relationship between words and sentences has meaning. Then, this meaning will tell the truth [5].

The multicultural discourse is part of the narrative in the textbook. This is because, since the independence of Indonesia, the founder of our nation has thought between their reality and expectation cleverly. In fact, Indonesian people have no single nation but they have pluralistic ethnic groups, religious beliefs, languages and political views [6]. Disclosure of historical discourse is important because the practice of discourse in history is a practice of discourse in general. It is also a social practice influenced by power or ideology [7].
Study of critical studies is related to the representation of the colonialism of New Order textbooks after the New Order was conducted by Hieronymus Purwanta. He focused on how historians established western culture as the Dutch colonialism as a determinant factor [8], while, on the other hand, the study of Bhineka Tunggal Ika discourse in historical textbooks was conducted by Indah Wahyu Puji Utami. Therefore, another author, Aditya Nugroho Widiadi, focused on the representation of 'Bhinneka Tunggal Ika' through history textbook theme [9].

Referring to the dynamic nature of textbooks, this study attempted to observe multicultural ideas in historical textbooks using the perspective of Hayden White, which is related to how history attempts to represent historical events through historical narratives contained in historical textbooks. White distinguishes between discourse, narrative, and narrative discourse based on the existence of subjectivity and objectivity in a narrative. The narrative contains a plot that shows how a narrative framework and plot were built close to a historical event. White states that the style of the historical narrative is influenced by the soul of the age and ideology, thereby causing the opportunity of changing the style of historical narrative in each age [10].

\section{Research method}

There were three history textbooks that become the board of this study, namely "Sejarah Indonesia" class X, XI, and XII revised edition of 2017 and 2018. "Sejarah Indonesia" textbook was part of the compulsory book in the Indonesian history lesson 2013 curriculum.

However, the production system in producing history textbooks of 2013 curriculum has been changed by the Department of Education (DoE). They also established a team which consisted of professional historians to write the textbook. The history textbook of 
2013 curriculum can be downloaded at buku.kemdikbud.go.id.

The researchers analyzed the history textbook using Discourse-Historical Approach (DHA) from Reisig and Wodak 2008 [11]. DHA was used as an approach to analyze and critically reveal the multicultural ideas stated in the history textbook entitled "Sejarah Indonesia".

The DHA principle toward the text was a reflection of the contestation power in society. Textbooks were part of a constitutive element of an ideology that exposed traces of indoctrination, transformation, and sociopolitical engineering of power in society. The purpose of DHA was to demystify hegemony by outlining constituted and dominative ideologies [12]. The approach included three layers of analysis: textual analysis, contextual analysis, and prospective criticism analysis. The focus of the analysis was on multicultural narratives. The textual analysis referred to the content of the book. The contextual analysis referred to the sociopolitical and historical background of the book that influenced contextual interpretation. Multicultural narratives were defined as the exact meaning of each object that could be used to educate and develop the cognitive, affective and psychomotor attitudes of learners.

\section{Research results and discussion}

\section{Multicultural textual analysis}

The Historical Textbook was a compulsory textbook of "Sejarah Indonesia" based on the updated Curriculum 2013. The 'Sejarah Indonesia' textbook was a compulsory textbook that was used by the students in their history learning in the classroom. Textually, the historical textbook Sejarah Indonesia for Class $\mathrm{X}$ is a single volume with three main chapters and several sub-chapters. The first chapter narrates bout "Menelusuri Peradaban Awal di Kepulauan Indonesia (Tracing the Early Civilization in the Indonesian Archipelago)".
The second chapter narrates about the "Pedagang, Penguasa, dan Pujangga pada Masa Klasik Hindu dan Budha (Traders, Rulers and Poets of the Hinduism and Buddhism Classical Period). The third chapter narrates about "Islamisasi dan Silang Budaya di Nusantara (Islamization and Cross Culture in the Archipelago)".

The "Sejarah Indonesia" textbook for Class XI consists of two volumes with seven main chapters. The first chapter narrates about "Antara Colonialism dan Imperialism (Between Colonialism and Imperialism)". The second is about "Perang Melawan Kolonialisme dan Imperialism (the War Against Colonialism and Imperialism)". The third chapter discusses the "Dampak Perkembangan Kolonialisme dan Imperialism (Impacts of the Development of Colonialism and Imperialism)". The fourth chapter narrates about "Sumpah Pemuda dan Jati Diri Keindonesiaan (Oath of Youth and Identity of Indonesia)". The fifth chapter is about "Tirani Matahari Terbit (The Sunrise Tyranny)". The sixth chapter is "Indonesia Merdeka (Indonesia Independence)". The seventh chapter is about the "Revolusi Menegakkan Panji-panji NKRI (Revolution Upholding the NKRI)".

Sejarah Indonesia textbook for Class XII comprises the following six chapters: 1) The Struggle Facing the Threat of Disintegration of the Nation; 2) The System and Structure of Indonesian Politics and Economy during the Period of Parliamentary Democracy (19501959); 3) Indonesia's Political and Economic System and Structure of Guided Democracy Period (1959-1965); 4) System and Political Structure of Indonesian Economy of the New Order Period (1966-1998); 5) Indonesia's Political-Economic System and Structure of the Reformation Period (1998-present); and 6) Indonesia on the Stage of the World".

In the 2013 Curriculum, Sejarah Indonesia textbook is one of the textbooks which must be studied by students. As a mandatory textbook for students, this book is structured with a popular regressive approach. This book invites 
students to observe the history through everyday life, through observation of socio-cultural conditions and a number of historical remains observable by students in the surrounding environment. From this observation, students were invited to explore the phenomenon around them by connecting it to a past event. It was expected that students were capable to think in causal thinking which could observe the cause of the event through many factors [13].

Based on the description, the textual meaning of the history textbook was instructed to students to enable them to write and describe every event that occurred and link the events in the region with national and global events. It was expected that students were able to understand the values of every historical event to strengthen mutual respect (tolerance) for diversity in all spheres of life.

\section{Multicultural contextual analysis}

The "Sejarah Indonesia" textbook which became the main object of this research was its up-to-date edition which was made based on the student's need during the learning process. This textbook was also based on the 2013 curriculum.

The multicultural discourse in that textbook was fabricated by local historians, known as modern professional historians. These professional historians were historians who graduated from a university. The authors of the history textbooks are historian scholars and historian educators. In this context, high school history textbooks were viewed as a historical document that contained 'the expression of the textuality of humans about their life as manifested through text or written content' and the particular production and reproduction of discourse [14]. By viewing explanations in school textbooks as the expression 'of subjects who have power and interest, text analysis not only surpasses the grammatical meaning but also more deeply explores the contextual meaning in order to understand the assumptions, ideology, and message that are discussed and presented in textbooks and delivered to students as the audience [15]. These assumptions, ideologies and discourse messages came in various forms of syntax; they can be terms, sentences or phrases [16].

In general, the context of multicultural narratives in Class $\mathrm{X}$ textbook was in through position of the ideas: nationalism, acculturation, cross-culturedness, trade relations, and national integration. The context of multicultural narratives in Class XI textbook was in a position of the ideas: the progress of the press, the emergence of the organization, and independence. Then in Class XII textbook, the multicultural context discussed the diversity of islands, tribes, religions, races, languages, buildings such as TMII (Taman Mini Indonesia Indah), and Penataran Pancasila. Intertextuality networks can be found between historical textbooks published by the Department of Education with the book "National History of Indonesia" and "Indonesia in the Flow of History".

The multicultural idea has not gained the main idea of narrative or discourse on historical textbooks. This is in accordance with Baha 'Uddin's statement that the multicultural idea in the textbook is not a great idea to be conveyed, the multicultural idea is an idea embedded in the textbook production process [17].

On the other hand, the multicultural narratives that exist in the history textbook need to have a further excavation, a new perspective and to be able to help build students' multicultural competence.

Multicultural narratives of the Sejarah Indonesia textbooks were divided into sub-discussion categories, namely historical relics space and historical events space. The sphere in question was the place where the historical event took place and the historical fact was located. The researchers tried to create the spatial category that was divided into two categories, namely Java and outside Java. This category was made through sociological and 
cultural realities of society in Indonesia that can be distinguished into Java and non-Java. Java Island is the most populous island and so are the Javanese who migrated outside of Java Island. Sociologically, Java as a cultural reality is more dominant in the life of society in Indonesia.

\subsection{Historical relics space}

This analysis has already done because the material found on history textbook is dominated by the pre-literacy and Hindhu-Buddist, and Islamic era. The explanation of the material in Class $\mathrm{X}$ textbook is divided into three chapters: 1) Tracing the early civilization in the Indonesian archipelago; 2) The traders, rulers, and poets of the classical period (Hindu and Buddhist); and 3) Islamization and cross-culturedness in the archipelago. Frankly speaking, based on the historical period of Indonesia, the subject matter of Class $\mathrm{X}$ historical textbook dates back prehistoric times, the Hindu-Buddhist era and the Islamic kingdoms.

Chapter I, Class X textbook, focuses on "Tracing the Early Civilization of the Indonesian Archipelago". This part of the spatial aspect studied was the place of discovery of early humans and the results of its culture although this is also evident in other places outside of Java. The center of the discovery of early humans in Indonesia was even defined as a world heritage, namely Sangiran.

Sangiran was first discovered and investigated by P.E.C. Schemulling in 1864, with reports on the discovery of vertebrate fossils from Kalioso. Then in 1934, Gustav Heindrich Ralph von Koenigswald discovered lytic artifacts in the Ngebung region. Sangiran became famous for the fossil findings of Homo erectus sporadically and continuously. Homo erectus was the most important taxon in human history, before entering the human stage of Homo sapiens or modern man.

As seen in terms of spatial relics, the discovery of ancient humans narrated in the textbooks tends to dominate the discovery in Java, although found outside of Java, the number and narration were still small. According to this textbook, "Ancient human remains the most widely found are on the island of Java. Although there are other places in the area, the researchers have not been able to locate the remains or there is still little to have been found, such as in Flores ..."

The narrative of ancient human discovery other than in Sangiran is also found in Trinil, Ngawi East Java. In Trinil Eugene Dubois discovered the remains of an early man called Pithecanthropus erectus. The discovery of early humans was also found in other areas around the Bengawan Solo River stream.

Narrative findings of ancient human technological tools in textbooks are still widely found on the island of Java which has been divided into two regions, namely Kebudayan Pacitan and Ngandong. The findings of human technology tools in textbooks were also found outside Java.

The discovery of ancient human culture technology was also found in Ngandong, East Java. Distribution of artifacts outside Java is described in the textbook narrative as follows: "The distribution of artifacts and paleolithic equipment was quite extensive in the regions of Sumatra, Kalimantan, Sulawesi, Bali, West Nusa Tenggara, East Nusa Tenggara and Halmahera".

Narratives about where the discovery of ancient human technological artifacts were also scattered outside of Java, but the explanation is less complete than that of the discovery in Java. Specifically, the above discovery mentions more the name of the island or province, not the explaining of where the place is exactly located.

Concerning the discovery of square axes, the textbook narrates, "the spread of these tools is mainly in the western islands of Indonesia, such as the west, Sumatra, Java, and Bali. It is suggested that the centers of this square ax technology are located in Lahat, Bogor, Sukabumi, Tasikmalaya, then Pacitan-Madiun, and on the slopes of Mount Ijen ... In Pasirkuda 
village near Bogor "asahan stone" was also found.

Then, the analysis of the spatial side had been done by observing the narrative text related to Hindhu-Buddist Kingdoms along with the evidence of its relics. Therefore, the discussion about Hindhu-Buddhist Kingdoms relics was dominated by the Hindhu-Buddhist Kingdom in Java such as Tarumanegara, Kalingga, Ancient Mataram, Kediri, Singhasari, and Majapahit; while, the Hidhu-Buddist Kingdoms beyond Java were Kutai, Sriwijaya, Buleleng, Warmadewa, Tulang Bawang, and Kota Kapur.

The first Hindu-Buddhist kingdom discussed in the textbook narrative was the Kutai Kingdom. This Kutai Kingdom was located in Mahakam River, East Kalimantan. The discussion of the kingdom after Kutai was the Tarumanegara Kingdom located not far from the north coast of western Java. Based on the inscriptions found, the center of Tarumanegara Kingdom was located between the Citarum River and Cisadane. Finally, the kingdom of Tarumanegara scattered in the area of Jakarta, Bogor, and South Banten.

The next discussion of the Hindu-Buddhist kingdom was Kalingga located in central Java. It was estimated that this work was in Kecamatan Keling, Jepara, Central Java or north of Mount Muria. The next kingdom was the Sriwijaya Kingdom located beyond Java Island, namely Sumatra. The discussion of Sriwijaya Kingdom was quite extensive. The kingdom of Sriwijaya lied in the center of his empire in Jambi or in Palembang, near the coast and the bank of Musi River. The Sriwijaya Kingdom heritage spread in various places, namely in Palembang, Bangka, and Jambi.

The Hindu Buddhist kingdoms in Java started from Ancient Mataram, Kediri Singhasari to Majapahit. Moreover, Majapahit Kingdom would be discussed in the next narratives theme book. Most of that kingdom was spread in Central Java and East Java.

The discussion of the Hindu-Buddhist kingdoms explained in the kingdom of
Buleleng and the Kingdom of the Warmadewa Dynasty in Bali. The royal narrative was not as extensive and deep as the narrative of the Hindu Buddhist kingdoms in Java. The final discussion was of the kingdom of Tulang Bawang in Lampung and Kapur City's kingdom on Bangka Island. Those kingdoms were not deeply narrated compared to the other Javanese Kingdoms.

The discussion of the Islamic kingdoms was presented in the chapter on Islamisasi dan Silang Budaya di Nusantara (Islamization and Cultural Cross in Nusantara). Therefore, the spatial aspects found in the discussion were related to the named Kingdoms.

The spatial aspects of Java and beyond Java discussion were explained in the same proportion compared to the discussion of the Hindu Buddhist kingdoms. In the discussion of the Islamic kingdom in the archipelago, every island there was Islamic-patterned one.

The first discussion of the Islamic empires in Sumatra referred to Samudra Pasai, Aceh Darussalam, Siak, Kampar, Indragiri, Jambi, and Palembang Sultanate. A narrative discussion of the kingdoms in Sumatra was quite extensive and deep, especially that of the kingdom of Samudra Pasai and Aceh Darussalam when compared with the discussion of the kingdoms of Siak, Kampar, Indragiri, Jambi, and Sultanate of Palembang.

The Islamic kingdoms in Java such as Demak Kingdom, Mataram Kingdom, Banten Sultanate, Sultanate of Cirebon were also discussed in the narration textbook. The territory of these kingdoms represented the territory of Java Island, namely the Demak Kingdom in Demak, the Mataram Kingdom in Yogyakarta or Central Java, Banten and Cirebon Sultanate in West Java.

The Islamic kingdoms of Kalimantan were mentioned in the narrative textbook as follows:

"The Sultanate of Pasir (1516), Sultanate of Banjar (1526-1905), Sultanate of Kotawaringin, Pagatan Kingdom (1750), Sambas Sultanate (1671), Kutai Kartanegara Sultanate, Berau Sultanate (1400), Sambaliung Sultanate (1810), 
Gunung Tabur Sultanate (1820), Pontianak Sultanate (1711), Tidung Sultanate, and the Sultanate of Bulungan (1731).

The Borneo Islamic Monarchy narrative story was not completely discussed. It only discussed Pontianak kingdom in West Kalimantan, Tanjungpura and Lawe, and Banjar Kingdom (Banjarmasin) in South Kalimantan.

While in Sulawesi Monarchy, there were a number of royal names stated in the narrative textbook, only a few of them were further discussed such as Gowa-Tallo and the Kingdom of Wajo. Written in that narrative textbook, were some of the Islamic Empires in Sulawesi namely Gowa-Tallo, Bone, Wajo and Soppeng and the Buton Sultanate.

Another discussion of the Maluku Islamic Kingdoms in historical textbooks remarked, "From the beginning, it was known that in that area there were two large Islamic-style kingdoms, namely Ternate and Tidore. Both of these kingdoms lied to the west of Halmahera Island, North Maluku. The centers of the two kingdoms were Ternate and Tidore Islands, but their territory included a number of islands in the Maluku Islands and Papua ".

The further explanation only referred to Ternate Monarchy. Therefore, the other Islamic kingdoms which related to Ternate such as Tidore, Bacan, Jailolo were not comprehensively explained, as in the following textbook: "In addition to the Kingdom of Ternate, you can find other sources about the Kingdom of Tidore, Bacan, Jailolo - part of Islamization in Ambon ".

The discussion of Islamic Kingdom in Papua in the narrative textbook was not in-depth enough, while some other Islamic kingdoms built in Papua were mentioned as follows:

"Sources of history show that the spread of Islam in Papua has been going on for a long time. In fact, based on historical evidence there are a number of Islamic kingdoms in Papua, namely: (1) Kingdom of Waigeo (2) Kingdom of Misool (3) Kingdom of Salawati (4) Kingdom of Sailor of (5) Royal Fatagar (6)
Rumbati Kingdom Atiati, Sekar, Patipi, Arguni, and Wertuar) (7) Kingdom of Kowiai (Namatota) (8) Kingdom of Aiduma (9) Kingdom of Kaimana ".

Actually, there was no further discussion about those nine Islamic kingdoms but the further explanation about them was the opinion about the coming of Islam in Papua.

The narratives about the Islamic kingdoms in Nusa Tenggara were associated with the Kingdom of Lombok and Sumbawa, the royal center located in Selaparang and the Kingdom of Bima in Bima Nusa Tenggara.

\subsection{Historical events space}

Researchers analyzed Class XI narrative textbook which contains the elements of multicultural discourse withing the historical events space. Class XI textbooks were selected as a part of this discussion because the narrations in that textbooks revealed many important events in the Indonesian history that began the period of Colonialism until the National Movement.

The aspect of the event in relation to the discussion of Colonialism and Imperialism showed that, "In 1610 Pieter Both left Banten succeeded in entering Jayakarta. The ruler of Jayakarta at that time, Prince Wijayakrama was very open in terms of trade. Merchants from anywhere were free to trade, in addition to the archipelago as well as from outside such as from Portugal, England, Gujarat / India, Persia, including the Netherlands. Thus, Jayakarta with its port of Sunda Kelapa became a very busy trading city.

The explanation above shows that the trade and hospitality of the local rulers of the archipelago attracted the foreign traders to come to Sunda Kelapa and met other traders from both insdie and outside of Indonesia.

The next discussion was presented in the chapter on "Perang Melawan Kolonialisme dan Imperialisme (A War Against Colonialism and Imperialism)" which was divided into subchapters, namely "Perang Melawan Kongsi Dagang dan Perang Melawan Penjajahan 
Belanda (War against Trade Conflicts and War against Dutch Colonialism)".

In the narrative of "Perang Melawan Kongsi Dagang (War Against Trade Conflicts)", the multicultural-filled narratives were fairly balanced. This can be seen in the textbook in terms of spatial events in the sub-chapters: "Aceh Versus Portugis dan VOC, Maluku Angkat Senjata, Sultan Agung Versus J.P Coen, Perlawanan Banten, Perlawanan Gowa, Rakyat Riau Angkat Senjata, Orang-Orang Cina Berontak dan Perlawanan Pangeran Mangkubumi dan Mas Sa'id (Aceh Versus Portuguese and VOC, Maluku Weapons, Sultan Agung Versus JP Coen, The Banten Resistance, the Gowa Resistance, the Riau People's Weapon, the Chinese Revolt and the Resistance of Prince Mangkubumi and Mas Sa'id )".

In the chapter of Perang Melawan Kongsi Dagang (War Against Dutch Colonialism), the discussion of the spatial events in Indonesia was balanced. It can be seen in the history textbook that the war in the area included: War Tondano, War Pattimura, Padri War, Diponegoro war, Resistance in Bali, Banjar War, Aceh War, Batak War.

Then the chapter on "Oath of Youth and Identity of Indonesia" in the textbook affected the youth who were educated in Europe. The experience gained by youth at school and in life after graduation is different from that of their older generation's. The educated young men then formed a "national" consciousness as bumiputra in the Indies, moving with other "nations" in the timeline leading to modernity.

The chapter " Sumpah Pemuda dan Jati Diri Keindonesiaan (The Oath of Youth and Identity of Indonesia)" contains many multicultural elements, which can be seen from the growing spirit of nationalism of different youths such as Jong Java, Jong Celebes, Jong Sumatranen Bond, Jong Islamieten Bond, Jong Batak Bond and others. There was rapid development of press in areas such as Batavia, Surakarta, Yogyakarta, Bandung, Surabaya, Padang, Semarang.
However, the youth associations and the press associations from different regions wanted a change which aimed at leading nationalism into independence. Thus, in this chapter, it can be seen that the multicultural is a part of the nationalist ideas.

In the chapter "Indonesia Merdeka", the multicultural elements can be found in the nationalism or independence ideas. It can be seen as "... evolved a very crucial issue related to the first precepts in Pancasila which is an inseparable part of the Preamble of the Constitution, "Deity with the obligation to enforce Islamic shari'ah for its adherents. The people of Eastern Indonesia who are generally Protestant and Catholic Christians objected to the formula ... all night Hatta imagined how the Republic of Indonesia without Eastern Indonesia, how the struggles that have been done for years together from both Islamic, Christian, Catholic and other religions. Bung Hatta, in his heart, asserted that Indonesia must remain united ..."

Specificcally, the multicultural and nationalism ideas in the textbook could be expressed as follows:

"... Unity and unity is a very important value in every form of struggle. All existing organizations or powers, albeit with different ideologies or organizations, remain united in the face of the colonizers to achieve independence. In the period of disarmament against Japan, the war against the Allies and the Dutch, all members of the TNI, various members of the united and the people united".

"... as the embodiment of the love of the homeland, the love of his blood spilled the various resistance in the region to fight against the power of the invaders. In Sumatra, in Java, Bali, Sulawesi and elsewhere, there is turbulence and resistance against foreign powers, for the sake of independence of their homeland".

The multicultural idea lied in the position of the scope of the idea of nationalism or unity towards independence gaining the attention that went on to the history text of the chapter 
"Perang Melawan Kolonialisme, Sumpah Pemuda dan Jati Diri Keindonesiaan, Tirani Matahari Terbit, dan Indonesia Merdeka (The War Against Colonialism, the Oath of Youth and the Identity of Indonesia, the Rising Sunrise, and the Independent Indonesia.)".

\section{Multicultural values in the textbook}

The multicultural narratives found in the textbook were the historical relics space and historical events space. Then multicultural narratives in the Sejarah Indonesia textbook can be developed into a multicultural competency that must be owned by students.

Gay (1995) described that it is important for the students to learn how to interact and understand people who are ethnic, racial, and culturally different from themselves [18]. The assumptions which turned into a goal in multicultural competence are "The reduction of racial and cultural prejudice is possible and desirable". Individuals can become multicultural; they didn't need to reject their familiar worldview and identity to function comfortably in another cultural milieu [19].

Multicultural competence includes the ability to interpret intentional communications (language, signs, gestures), unconscious cues (such as body language), and customs in cultural styles different from one's home culture. It varies along a continuum of high to low, and the interculturally competent person can communicate and empathize to some degree with culturally different others and is well aware of his or her own culturally conditioned assumptions. Since an individual's knowledge, attitudes and beliefs are limited by opportunities to experience and learn about the cultural heritage of his or her primary heritage group, there is a great deal of diversity within any one group

On the other hand, the competence that must be possessed by an individual in society explained by Bennet (1995). He stated that the idea of multicultural competence is the disposition of open-mindedness and the absence of racial or cultural prejudice, and knowledge of world views and knowledge funds related to various cultural groups, as well as diversity within and between ethnic groups [20].

The findings of the multicultural narrative in the textbook reflected the four competencies of the human. This is in line with the standard competence determined by Department of Education (DoE) (2016) as follows: 1) Spiritual competence, living and practicing the teachings it embraces. It can be understood by students from the struggle of independence heroes composed of various united religions to achieve the ideals towards an independent Indonesia. 2) Tolerance as part of the solution to various problems in interacting effectively with the social and natural environment and in placing itself as a reflection of the nation in the association of the world. This reflected the Rengasdengklok incident that was caused not by the different views between the youth with the old group, but because mutual understanding and mutual respect, then the agreement can be achieved. 3) Knowledge: understanding, applying, analyzing factual, conceptual, procedural knowledge based on diverse Indonesian society and for solving problems. 4) Skills: cultivating, reasoning and chanting in the realm of abstract and abstract related to the development of the self-studied and using methods according to scientific rules.

\section{Conclusion}

The "Sejarah Indonesia" textbook reflects textual, contextual and multicultural meanings. Textually, the history textbooks contain the multicultural narratives. The multicultural narrative contextually can be found throughout the book, especially in the categorization of historical relics space and historical events space. Textual and contextual meanings can be the basis or paradigm of education policy and praxis as a multicultural competence that is owned by the students themselves, both in 
solving problems in the classroom as well as in human life.

The findings indicate that this textbook is important for educational purposes in the area of multicultural competence. Thus, the continuation of this book for further analysis in the field of education is quite open, for example in the learning model with other relevant material and so on. The researchers suggest further developing the book, both from the material field and exploring the potential possessed by students to transmit the multicultural values of books to students.

\section{References}

[1] Wineburg, Sam, Historical Thinking and Other Unnatural Acts, Charting the Future of Teaching the past. Philadelphia: Temple University Press, 2001.

[2] Abdullah, Taufik, "Kata Pengantar" dalam Sartono Kartodirjo. Sejak Indisch sampai Indonesia, Jakarta: Penerbit Buku Kompas, 2005.

[3] Nordholt, H.S, Purwanto, B dan Saptari, R. Ed, Perspektif Baru dalam Penulisan Sejarah Indonesia, Jakarta: Yayasan Obor Indonesia, 2003.

[4] Marwick, Arthur, The Nature of History, London: Macmillan, 1992.

[5] McCullagh, C.Behan, The Truth of History, London: Routledge, 1998.

[6] Wasino, Indonesia: From Pluralism to Multiculturalism, Paramita: Historical Studies Journal 23 (2013) 148.

[7] Van Dijk, Teun, A, Ideology, Sage Publications, 1998.

[8] Purwanta, H, The representation of colonial discourse in Indonesian secondary education history textbook during and after the New Order (1975-2013), History Education (2017) 1.

[9] Utami, Indah Wahyu Puji \& Widiadi, Aditya Nugroho, Wacana Bhineka Tunggal Ika dalam
Buku Teks Sejarah, Paramita: Historical Studies Journal 26 (2016) 106.

[10] White, H, The Content of the Form: Narrative Discourse and Historical Representation, Baltimore and London: The Hopkins University Press, 1987.

[11] Reisigl, M, \& Wodak, R, The discourse-historical approach (DHA). In R. Wodak, \& M. Meyer, Methods for Critical Discourse Analysis (p. 88), London Sage, 2008.

[12] Haryatmoko, Critical Discourse Analysis (Analisis Wacana Kritis) : Landasan Teori, Metodologi dan Penerapan), Jakarta: PT RajaGrafindo Persada, 2016 \& Reisigl, M, \& Wodak, R, The discourse-historical approach (DHA). In R. Wodak, \& M. Meyer, Methods for Critical Discourse Analysis (p. 88), London Sage, 2008.

[13] Sardiman AM, Lestariningsih, Amurwani Dwi, Sejarah Indonesia untuk SMA/MA/SMK/MAK Kelas XI Semester 2 (Jilid IIb), Jakarta: Kementerian Pendidikan dan Kebudayaan, 2017.

[14] Wodak, Ruth \& Meyer, Michael, eds., Methods of Critical Discourse Analysis, London: Sage, 2006.

[15] Crawford, Keith, Construction National Memory: The 1940/41 Blitz in British History Textbooks, in Internationale Schulbuchforschung, vol. 23, Hannover: verlag Hahnsche Buchhandlung, 2001.

[16] Van Dijk, Teun A, Ideology and Discourse: A Multidisciplinary Introduction, Barcelona: Pompeu Fabra University, 2000.

[17] Interview with Baha' Uddin, Soothsayer Text Books History for Curriculum 2013. 10-Mei-2018

[18] Gay, G, A synthesis of scholarship in multicultural education, Oak Brook, IL: North Central Regional Educational Laboratory, 1995.

[19] Bennett, Christine, Genres of Research in Multicultural Education, Review of Educational Research, Vol.72,2 (2001).

[20] Bennett, C.I, Research on racial issues in American higher education, In J.A. Banks \& C.M. Banks (Eds), Handbook of research on multicultural education, New York: Macmillan, 1995. 


\title{
Nội dung đa văn hóa trong sách giáo khoa Lịch sử
}

\author{
Akhmad Dwi Afiyadi, Leo Agung Sutimin, Sunardi \\ Khoa Lịch sủ, Trường Đại học Sebela, Surakarta, In-đô-nê-xi-a
}

Tóm tắt: Sách giáo khoa lịch sử là tài liệu học sinh sử dụng trong quá trình học tập môn Lịch sử theo Khung chương trình năm 2013. Sách giáo khoa này sử dụng cách tiếp cận hồi quy phổ biến. Tập sách khuyến khích học sinh quan sát các sự kiện lịch sử diễn ra trong cuộc sống hàng ngày cũng như những sự kiện đã xảy ra. Các nhà nghiên cứu sử dụng phương pháp tiếp cận Lịch sử-Diễn ngôn của Ruth Wodak để phân tích sách giáo khoa. Theo cách tiếp cận này, quyển sách được phân tích theo ba góc độ: phân tích văn bản, phân tích hoàn cảnh và phân tích phê phán tiềm năng. Nhìn từ góc độ hoàn cảnh, nội dung đa văn hóa được thể hiện xuyên suốt cuốn sách, đặc biệt là thông qua việc phân nhóm sự kiện thành không gian di tích lịch sử và không gian sự kiện lịch sử. Ý nghĩa văn bản và hoàn cảnh của sách giáo khoa có thể làm cơ sở hoặc nền tảng cho chính sách giáo dục cũng như năng lực đa văn hóa của học sinh được thể hiện qua việc giải quyết các vấn đề trên lớp cũng như các vấn đề trong cuộc sống hàng ngày. Sách giáo khoa có vai trò quan trọng đối với các mục đích giáo dục trong môi trường đa văn hóa. Việc viết tiếp cuốn sách này để phân tích sâu hơn các vấn đề trong lĩnh vực giáo dục là khá cởi mở, ví dụ như trong mô hình học tập sử dụng các tài liệu liên quan khác. Các nhà nghiên cứu đề xuất phát triển cuốn sách, cả về mặt nội dung lẫn khám phá tiềm năng của học sinh để truyền tải các giá trị đa văn hóa của sách cho học sinh.

Tù khóa: Sách giáo khoa Lịch sử, nội dung đa văn hóa, phương pháp tiếp cận Lịch sử - Diễn ngôn, năng lực đa văn hóa, giá trị đa văn hóa. 